This is the final peer-reviewed accepted manuscript of:

GIAMBASTIANI, BEATRICE MARIA SOLE; COLOMBANI, NICOLÒ; GREGGIO, NICOLAS; ANTONELLINI, MARCO; Mastrocicco, Micòl: Coastal aquifer response to extreme storm events in Emilia-Romagna, Italy. HYDROLOGICAL PROCESSES 31. 0885-6087

DOI: $10.1002 /$ hyp.11130

The final published version is available online at: $\underline{\text { http://dx.doi.org/10.1002/hyp.11130 }}$

Rights / License:

The terms and conditions for the reuse of this version of the manuscript are specified in the publishing policy. For all terms of use and more information see the publisher's website.

This item was downloaded from IRIS Università di Bologna (https://cris.unibo.it/)

When citing, please refer to the published version. 


\title{
Coastal aquifer response to extreme storm events in Emilia-Romagna, Italy
}

\author{
Beatrice M.S. Giambastiani ${ }^{1}$ | Nicolò Colombani ${ }^{1} \quad$ Nicolas Greggio $^{1}$ \\ Marco Antonellini ${ }^{1} \quad$ Micòl Mastrocicco ${ }^{2}$
}

${ }^{1}$ BiGeA Biological, Geological and Environmental Sciences, University of Bologna, 40126 Bologna, Italy

${ }^{2}$ DISTABIF Department of Environmental, Biological and Pharmaceutical Sciences and Technologies, Second University of Naples, Via Vivaldi 43, 81100 Caserta, Italy

Correspondence

Nicolò Colombani, BiGeA Biological, Geological and Environmental Sciences, University of Bologna, 40126 Bologna, Italy. Email: nicolo.colombani2@unibo.it

\begin{abstract}
With global warming and sea level rise, many coastal systems will experience increased levels of inundation and storm flooding, especially along sandy lowland coastal areas, such as the Northern Adriatic coast (Italy). Understanding how extreme events may directly affect groundwater hydrology in shallow unconfined coastal aquifers is important to assess coastal vulnerability and quantify freshwater resources. This study investigates shallow coastal aquifer response to storm events. The transitory and permanent effects of storm waves are evaluated through the real time monitoring of groundwater and soil parameters, in order to characterize both the saturated and unsaturated portions of the coastal aquifer of Ravenna and Ferrara (southern Po Delta, Italy). Results highlight a general increase in hydraulic head and soil moisture, along with a decrease in groundwater salinity and pore water salinity due to rainfall infiltration during the 2 days storm event. The only exceptions are represented by the observation wells in proximity to the coastline (within $100 \mathrm{~m}$ ), which recorded a temporary increase in soil and water salinity caused by the exceptional high waves, which persist on top of the dune crest during the storm event. This generates a saline plume that infiltrates through the vadose zone down to the saturated portion of the aquifer causing a temporary disappearance of the freshwater lens generally present, although limited in size, below the coastal dunes. Despite the high hydraulic conductivity, the aquifer system does not quickly recover the pre-storm equilibrium and the storm effects are evident in groundwater and soil parameters after 10 days past the storm overwash recess.
\end{abstract}

\section{KEYWORDS}

coastal aquifer, seawater intrusion, storm event, storm surge, vadose zone

\section{1 | INTRODUCTION}

With global warming and sea level rise, many coastal systems will experience increased levels of inundation and storm flooding, accelerated coastal erosion, seawater intrusion into fresh groundwater, encroachment of tidal waters into estuaries and river systems, and elevated sea surface and ground temperatures. Particularly at risk are the large delta regions and midlatitude temperate coasts, often comprising lowland coastal plains and barriers and soft sedimentary cliffs (IPCC, 2001). In particular, sea level rise associated with climate change (by way of changes to atmospheric pressure, expansion of oceans and seas as they warm, and melting of ice sheets and glaciers) is one potentially significant process that is very likely to play a major role in seawater intrusion in coastal aquifer (Ketabchi, Mahmoodzadeh, Ataie-Ashtiani, \& Simmons, 2016;
Werner \& Simmons, 2009). For an unmitigated future increase in emissions (Representative Concentration Pathways, RCP8.5), IPCC predicts a global sea level rise by $52-98 \mathrm{~cm}$ by the end of this century (IPCC, 2013). In addition, a changing climate leads to changes in the frequency, intensity, spatial extent, duration, and timing of weather events, which can result in unprecedented extreme events (IPCC, 2012).

Understanding how extreme events may directly affect groundwater hydrology in shallow unconfined coastal aquifers is important when assessing the vulnerability of coastal zones and freshwater resources. Coastal aquifers are complex because of the combined influences of marine oscillations and landward groundwater gradients (Vallejos, Sola, \& Pulido-Bosch, 2015). Coastal groundwater hydrodynamics are the result of combined forces from tidal motion (Guo, Jiao, \& Li, 2010), wave setup and wave run-up (Nielsen, 1999), atmospheric pressure 
variations (Balugani \& Antonellini, 2011), storm surges (Yang, Graf, Herold, \& Ptak, 2013), and wind setup (Giuliano \& Manda, 2012).

Extreme storm events and the subsequent wave overwash have the potential to result in severe consequences for freshwater resources because of salt contamination (Anderson, 2002). During and following overwash inundation, saltwater contamination can occur through infiltration of seawater through the vadose zone (Illangasekare et al., 2006); the saltwater plume moves downward through the shallow freshwater lenses due to the density and hydraulic gradients that drive coastal groundwater flow (Holding \& Allen, 2015; Terry \& Falkland, 2010).

Coastal aquifer processes and response of the salt-freshwater interface under intensified wave conditions caused by storms and time-varying wave forcing conditions have been widely investigated by numerical (Cartwright, Li, \& Nielsen, 2004a; Holding \& Allen, 2015; Robinson, Xin, Li, \& Barry, 2014; Xin, Robinson, Li, Barry, \& Bakhtyar, 2010), as well as physical models (Cartwright, Nielsen, \& Li, 2004b). Few are available regarding the impact of wave overwash on vadose zone (Holding \& Allen, 2015). Although these studies well simulate the hydrodynamic processes, they are not based on field data and are not supported by monitoring observations.

Coastal areas and coastal aquifers are thus highly vulnerable environments and may experience severe impacts from coastal storms. This is particularly true along the sandy lowland coastal area of the Emilia-Romagna region (Italy), where coastal inundations due to storm waves and surges are capable of flooding large areas (both natural and urbanized) causing major devastation (Ciavola et al., 2007; Harley et al., 2015). In this context, the objective of this study is to investigate the shallow coastal aquifer response to exceptional storm events that brought to unexperienced flooding conditions. The study is based on an interesting dataset that allowed studying aquifer dynamics during storm events in both saturated and vadose zones. The transitory and permanent effects of the storm waves and the concurrent inundation were evaluated by real time monitoring of groundwater and soil parameters, in order to disentangle the complex dynamics of both the saturated and unsaturated portions of the coastal aquifer. The monitoring was done in two different sites located in low-lying areas at the south of the Po Delta, along the Northern Adriatic coast (Italy).

\section{1 | Study areas}

The study areas are located in the coastal floodplain of the Po River, in northern Italy (Figure 1). Generally, it is a complex territory characterized by an important environmental value (dunes, pine forests, wetlands, etc.) where different socioeconomic interests coexist (tourism, industry, agriculture, port activities, etc.) and interfere with natural geomorphological processes, increasing chances for erosion and causing environmental stress to the dune-beach system (Sytnik \& Stecchi, 2014). Most of the territory is reclaimed land with flat topography at or below the sea level, with an altitude ranging from 5 to $11 \mathrm{~m}$ above sea level. The dune systems, palaeodunes, and river banks are the only topographical elevated structures of the area. The surface hydrographic system and water discharge towards the sea is guaranteed by a capillary drainage network. Several natural and anthropogenic features threaten this area: saltwater intrusion in the unconfined aquifer and seawater encroachment inland along the rivers (Giambastiani, Antonellini, Oude Essink, \& Stuurman, 2007); palaeo-seawater upward seepage through the hypersaline aquitard (Caschetto, Colombani, Mastrocicco, Petitta, \& Aravena, 2016; Colombani, Osti, Volta, \& Mastrocicco, 2016a); natural and anthropogenic land subsidence (Taramelli, Di Matteo, Ciavola, Guadagnano, \& Tolomei, 2015); soil salinization (Colombani et al., 2016b); high demand of water during the tourist season; insufficient aquifer recharge; and sea level rise (Antonellini et al., 2008).

These low-lying coastal areas are susceptible to marine inundation from severe storm events (Masina, Lamberti, \& Archetti, 2015; Perini,
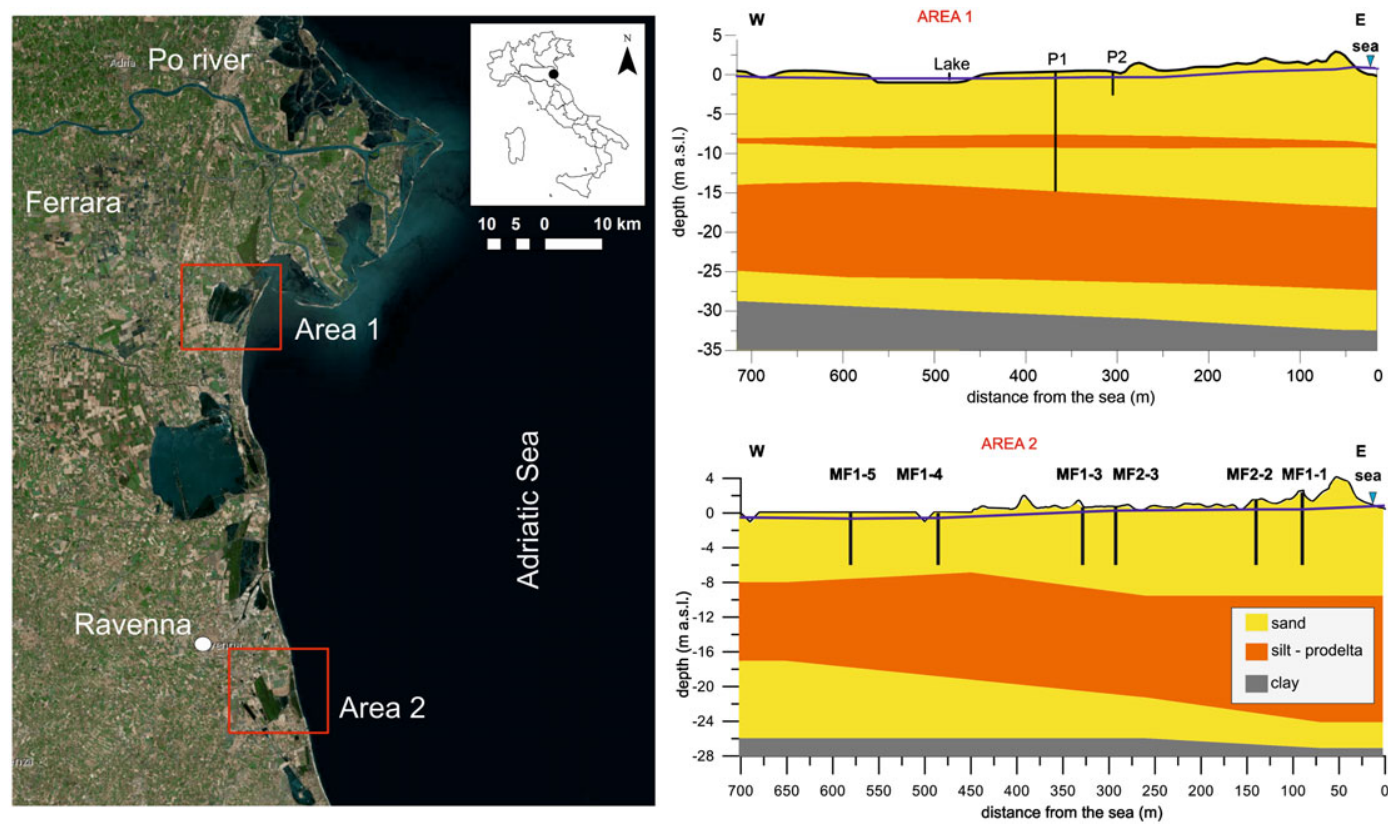

FIGURE 1 Location of the two study sites in the Po Plain: the coastal aquifers of Ferrara (Nazioni Lake, Area 1) and Ravenna (Lido di Dante pine forest, Area 2). Two cross sections (right side) perpendicular to the coastline, show the location of the monitoring points and the hydrogeological setting of the shallow coastal aquifer 
Calabrese, Salerno, Ciavola, \& Armaroli, 2016). Coastal protection is achieved by groynes and breakwaters offshore and, during the winter season, by artificial sand embankments built in front of the beach to prevent inundation and damage by strong winter storms. Prior to the beginning of the summer tourist season, the sand is mechanically redistributed along the beach profile, which can be considered completely artificial (Armaroli et al., 2012).

Moreover, along the Emilia-Romagna coast, dune systems have been damaged or destroyed over the last century, mainly as a result of tourism development; nowadays, residual dune systems are found only along the Ravenna and Ferrara coasts (Corbau, Simeoni, Melchiorre, Rodella, \& Utizi, 2015). Dunes not only provide a reserve supply of sand for protection against storm events and beach erosion but also absorb the impact of storm surge and high waves preventing or delaying flooding of inland areas and damage to inland structures (Ciavola et al., 2007).

Area 1 in Figure 1 is located in the Ferrara coastal area, close to Nazioni Lake, which is a man-made shallow coastal lagoon. Nazioni Lake runs parallel to the coast and is separated from the Adriatic Sea by the $0.5-\mathrm{km}$ wide Nazioni spit. Initially connected to the sea by a channel closed in the 1970s, now it receives intermittent freshwater discharge through a narrow channel regulated by a flood gate (Mistri \& Rossi, 1999), located on the mouth of the Po di Volano, an artificial canal that drains water from most part of the Ferrara Province (Castaldelli et al., 2013). The water temperature ranges between $29.9{ }^{\circ} \mathrm{C}$ (summer) and $2.3^{\circ} \mathrm{C}$ (winter), and salinity ranges between 24 and $31 \mathrm{~g} / \mathrm{L}$ with an average concentration of $27 \mathrm{~g} / \mathrm{L}$ (ARPAe, 2010).

Area 2 in Figure 1 is located in the Ravenna coastal area, close to Lido di Dante and the adjacent coastal pine forest that grows on the remains of the natural dune belt. This nonnative coastal forest was planted at the beginning of the 20th century to stabilize the sand and protect inland crops from sea spray. In July 2012, a large fire devastated 56 hectares of the natural reserve and 19 hectares of the forest were completely destroyed and left with bare soil and neither pine trees nor bushes. This natural environment and the beach-dune system represent the only recharge area for the coastal aquifer, because here the aquifer is unconfined and rainfalls can infiltrate. Due to the low topography, a high rate of natural and anthropic subsidence and a heavy drainage system across the pine forest and the agricultural crops, the coastal aquifer is completely compromised by marine ingression, with brackish to saline groundwater (Giambastiani, Greggio, Pacella, lodice, \& Antonellini, 2014).

\section{2 | Winter storm event (February 5 6, 2015)}

On February 5-6, 2015, a deep barometric pressure low on the western part of Italy produced abundant snowfall and rain in the alluvial plain of the Emilia-Romagna region causing severe damage. Abundant rainfall events occurred especially on the Ferrara and Ravenna territories, with daily rainfall in excess of $100 \mathrm{~mm} /$ day. The results were flooding situations both across the Apennines and the alluvial plain areas.

Concomitantly with this event, an intensification of the NE winds on the coast (bora wind with speed of $33-44 \mathrm{~km} / \mathrm{hr}$, with gusts up to $86 \mathrm{~km} / \mathrm{hr}$ ) lasting for 2 days, created rough sea conditions with waves up to $4 \mathrm{~m}$. These conditions, in combination with a sea level surge of $1 \mathrm{~m}$, produced a ruinous storm all along the Emilia-Romagna coast (ARPAe, 2015). This storm event was exceptionally strong, with a recurrence interval of 100 years for seawater level and 10 years for wave height (Perini, Calabrese, Lorito, \& Luciani, 2015). This is particularly evident when compared with historical time series, especially for the combination of wave height and seawater level, which both remained above the threshold of criticality identified for the alert event (wave height exceeding $2 \mathrm{~m}$ and sea level exceeding $0.7 \mathrm{~m}$ ) for a total of $21 \mathrm{hr}$ over 3 days (ARPAe, 2015).

\section{3 | Hydrogeological setting}

The stratigraphy of the area records the depositional evolution from low-stand continental accumulation to marine transgression and high-stand progradation occurring during the eustatic and climatic fluctuations that controlled the Quaternary environmental evolution and sequence stratigraphy of the Po Delta (Amorosi, Maselli, \& Trincardi, 2016).

The hydrogeological setting (Figure 1) of the coastal aquifer is characterized by two sandy units, transgressive bay and barrier deposits at the base, and prograding sandy deltaic lobes and strand plains at the top of the aquifer, intercalated by fine prodelta sediments with alternations of silt, clay, and sand layers (Amorosi, Colalongo, Pasini, \& Preti, 1999). Fine alluvial sediments at the bottom of sand deposits form the impermeable and confining unit.

In the study areas, the shallow coastal aquifer thickness ranges from $30 \mathrm{~m}$ in Area 1 to $25 \mathrm{~m}$ in Area 2. The hydraulic conductivity is variable ranging from $10^{3}$ at the top to $10^{6} \mathrm{~m} / \mathrm{s}$ at the bottom of the aquifer depending on the sorting of sand and the relative amounts of silt and clay (Giambastiani, Colombani, Mastrocicco, \& Fidelibus, 2013; Mastrocicco, Giambastiani, Severi, \& Colombani, 2012).

\section{2 | METHODS}

Two profiles, perpendicular to the coastline, were chosen in the two study areas to monitor the shallow coastal aquifer (Figure 1). The profile across the coastal aquifer of Ferrara (Area 1) was equipped with three level-loggers LTC Solinst for monitoring head, temperature, and electrical conductivity every $30 \mathrm{~min}$. Two probes were installed in piezometers P1 and P2 and one in the Nazioni Lake, at $20 \mathrm{~m}$ from the shoreline (along a floating dock) and about $-0.20 \mathrm{~m}$ below the water surface. A 5TE TDR sensor (Decagon Devices, Inc., Pullman, WA) measuring volumetric water content, temperature, and bulk soil electrical conductivity $\left(E C_{b}\right)$ was installed $0.4-0.5 \mathrm{~m}$ below the ground (close to P1) to monitor the unsaturated portion of the coastal aquifer. The probe was connected to a data logger recording every $30 \mathrm{~min}$.

The profile across the Ravenna coastal aquifer was equipped with three piezometers (MF1-1, 1-3, and 1-4) each having one level-logger LTC Solinst for monitoring, every $30 \mathrm{~min}$, water level and groundwater parameters, such as Area 1. The monitoring of the vadose zone was done on three vertical transects (MF1-5, 2-2, and 2-3), each one equipped with three 5TE TDR probes (Decagon Devices, Inc., Pullman, WA) at the depth of $-0.15,-0.40$, and $-0.70 \mathrm{~m}$ below the ground, for real time monitoring of soil water content, temperature, and $E C_{b}$. 
The hydrostatic pressure data measured by level-loggers were converted into water levels considering the atmospheric pressure data recorded by the weather stations of Ravenna and Ferrara; subsequently, water levels were converted into equivalent freshwater heads $\left(H_{f}\right)$ on the basis of the equation reported in Post, Kooi, and Simmons (2007), which takes into account variable density and salinity.

Electrical conductivity values $(\mathrm{mS} / \mathrm{cm})$ were converted into salinity (g/L) using the conversion formula of Lewis and Perkin (1981).

Regarding soil parameters, $E C_{b}(\mathrm{dS} / \mathrm{m})$ measured by Decagon soil probes was converted into pore water conductivity $(\mathrm{mS} / \mathrm{cm})$ and then into pore water salinity $(\mathrm{g} / \mathrm{L})$ using the conversion formula in Hilhorst (2000) and suggested in the Decagon Devises (2015).

Sea level and sea temperature were collected by the tide gauge of Porto Corsini (Ravenna) included in the Permanent Service for Mean Sea Level (http://www.psmsl.org/), and precipitation and air temperature data were derived from the Ravenna and the Volano weather stations, both included in the Hydro-Meteo-Climate service of the Emilia-Romagna region (Dexter system, http://www.arpae.it/).

The time interval of datasets considered in this paper goes from January 23 to February 18, 2015 for including all data related to the winter storm event that affected the whole Emilia-Romagna coast on February 5-6, 2015.

\section{3 | RESULTS}

Results of the groundwater monitoring are reported in Figure 2 for both study areas. The prestorm event $H_{f}$ in the Ferrara site shows an appreciable difference between P1, P2, and the Nazioni Lake. This difference is due to an upward groundwater flux induced by confined conditions of the aquifer below the silty-clay lens that divide the aquifer (Figure 1). The $H_{f}$ measured at the bottom of the aquifer with a straddle packer system was $0.35 \mathrm{~m}$ higher than in the upper portion of the aquifer, thus inducing upward groundwater seepage prevalent to the horizontal groundwater flux (Colombani et al., 2016a). The prestorm event $H_{f}$ in the Ravenna site shows an inland oriented groundwater flow, with an $H_{f}$ mean gradient of approximately $2 \%$ decreasing landward. The latter features are quite common in this zone (Antonellini et al., 2008). As regard the storm event perturbations, the $\mathrm{H}_{f}$ shows a rapid increase in all monitored piezometers (P1 and P2 in Ferrara, Figure 2a; MF1-1, 1-3, and 1-4 in Ravenna, Figure 2b) and in the Nazioni Lake due to the heavy rain events that occurred from February 4 to 7 (95 mm in Ravenna and $50 \mathrm{~mm}$ in Ferrara). Previous rain events were recorded in Ferrara, with a total of $28.5 \mathrm{~mm}$ between January 30 and February 2, causing an initial increase in $\mathrm{H}_{f}$.

In Figure 2, the sea level shows a maximum value of $1.21 \mathrm{~m}$ at 11:40 p.m. on February 5, which is the highest level ever recorded (since the beginning of 1900) by the tide gauge of Porto Corsini, Ravenna (ARPAe, 2015). The previous maximum value recorded by this station was $1.16 \mathrm{~m}$ on October 31, 2012, during another storm event (Harley et al., 2015).

The storm peak was observed by all level-loggers installed in the aquifer, with an increase in $H_{f}$ of about $0.5 \mathrm{~m}$ and a maximum of $1.75 \mathrm{~m}$ in the piezometer MF1-1, which is the closest to the sea. After the storm, the $H_{f}$ slowly returned to the initial value, but after 10 days was still above the average winter value, indicating a persistent effect of the storm event on the coastal aquifer.

It is important to note that the monitoring records in MF1-1 stop on February 15 because the level-logger was removed by sea waves that hit the dune crest.

The water level in the Nazioni Lake (Figure 2a) increased by $0.25 \mathrm{~m}$ suggesting hydraulic connection between surface and groundwater, given that in such a period, no inflow from the canal was allowed, that only $78.5 \mathrm{~mm}$ of rain fell, and that the flat topography does not allow for large amounts of run-off.

Figure 3 shows the salinity values recorded in both study areas and highlights the decrease in salinity at all observation points due to
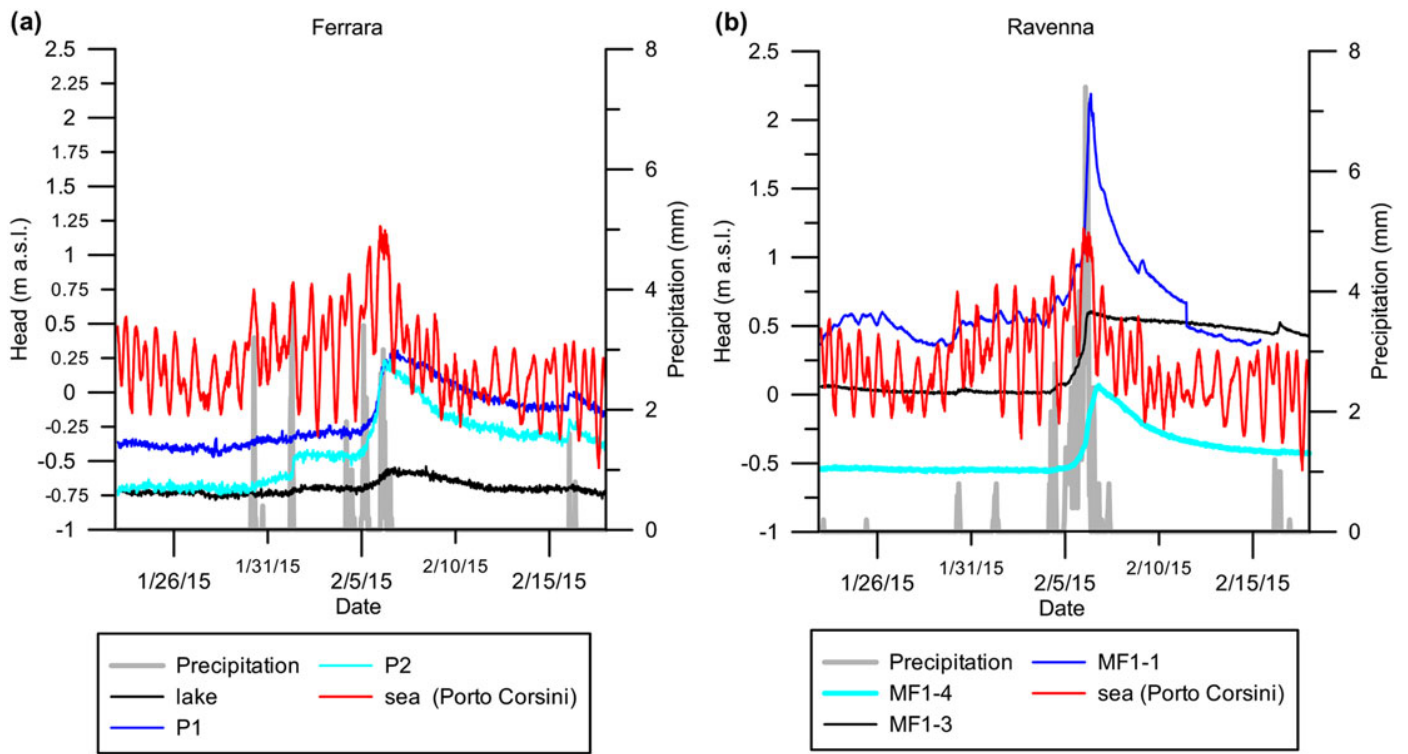

FIGURE 2 Freshwater heads ( $m$ above sea level [a.s.l.]) measured in the piezometers of (a) Ferrara and (b) Ravenna (Area 1 and Area 2, respectively, refer to Figure 1 for the locations) from January 23 to February 18, 2015. Sea level data ( $m$ a.s.l.) from the tide gauge of Porto Corsini and water level ( $\mathrm{m}$ a.s.l.) of the Nazioni Lake are reported on the left axes; precipitation $(\mathrm{mm}$ ) from the Volano (Ferrara) and the Ravenna weather stations are reported on the right axes 

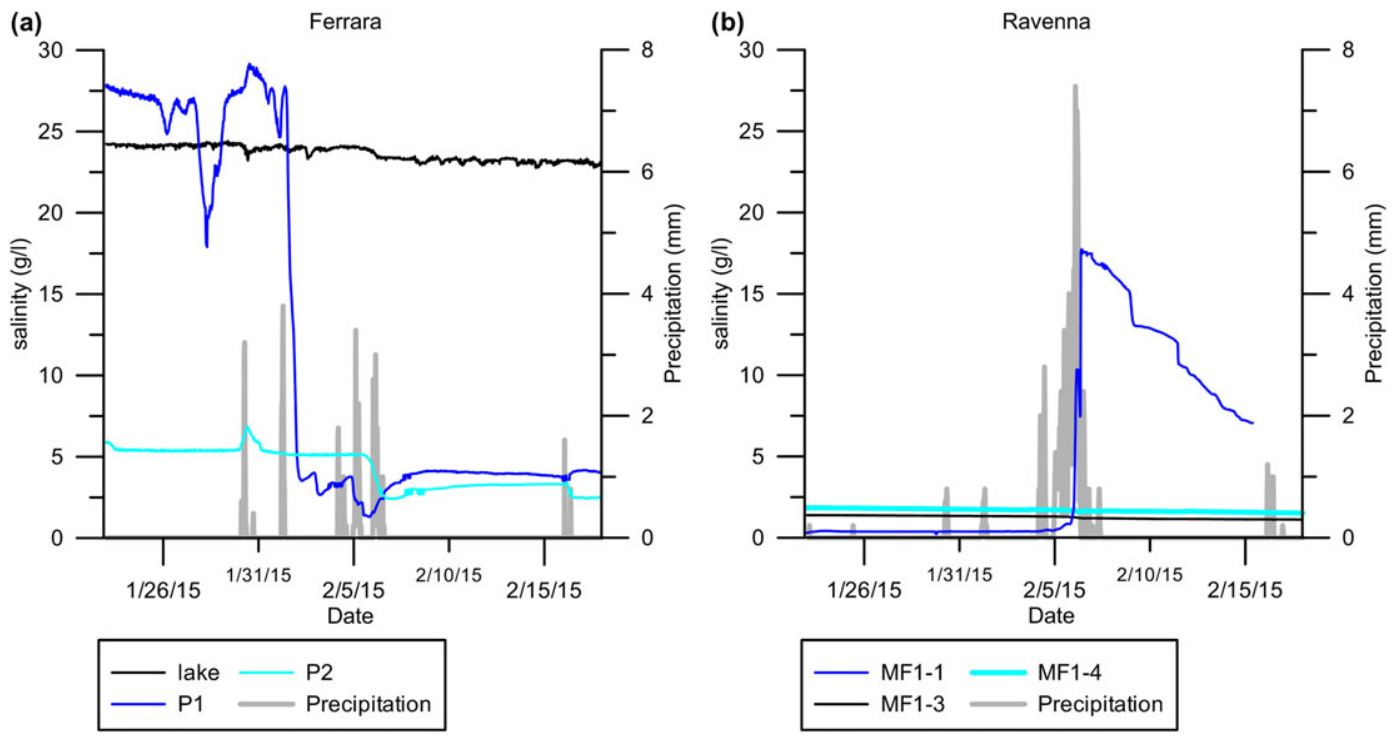

FIGURE 3 Salinity ( $\mathrm{g} / \mathrm{L}$ ) values recorded in the Nazioni Lake and in piezometers of both study areas (refer to Figure 1 for the location of the monitoring points). Precipitations $(\mathrm{mm})$ from the Volano and Ravenna weather stations are also shown

rainfall infiltration. However, in the Ravenna site, the MF1-1 showed a rapid salinity increase of about $14 \mathrm{~g} / \mathrm{L}$, from 0.4 to $17.5 \mathrm{~g} / \mathrm{L}$ during the main storm event that occurred on February 5-6, 2015. The Nazioni Lake recorded a little change in salinity during the storm event, from 23.8 to $22.6 \mathrm{~g} / \mathrm{L}$.

Figures 4 and 5 show results of the soil monitoring in both study areas. During the storm event, the vadose zone underwent a concurrent increase in soil moisture and decrease in pore water salinity at all observation points, except for MF2-2 in Ravenna (Figure 4b). This piezometer is a distant $150 \mathrm{~m}$ from the coastline and was directly impacted by sea inundation once the coastal dune was destroyed during the 2 days storm event.

In the Ferrara site (Figure 4a), the pore water salinity decreased about $64 \%$ and $67 \%$ following the two rain events (end of January and February 5-6 storm), and soil moisture values doubled and the vadose zone became completely saturated. In the Ravenna site (Figure $4 \mathrm{~b}$ ), the soil reacted similarly to the precipitation event, with a decrease of the pore water salinity of about $30 \%$ except for the piezometer MF1-1 on the dune crest where the pore water salinity increased from 0.4 to $1.5 \mathrm{~g} / \mathrm{L}$. Again, as recorded in the Ferrara site, the soil moisture increased reaching the complete saturation of the vadose zone due to the rainfall infiltration.

Figure 5 displays soil, air, sea surface, and groundwater temperatures. Soil and sea surface show a similar temperature trend, with diurnal oscillations, which are similar but more attenuated than air temperature oscillation. One exception to such behaviour is the MF1-5 filter port 3, where after the main storm event on February 5-6, 2015 a sudden pulse increase in temperature was recorded.
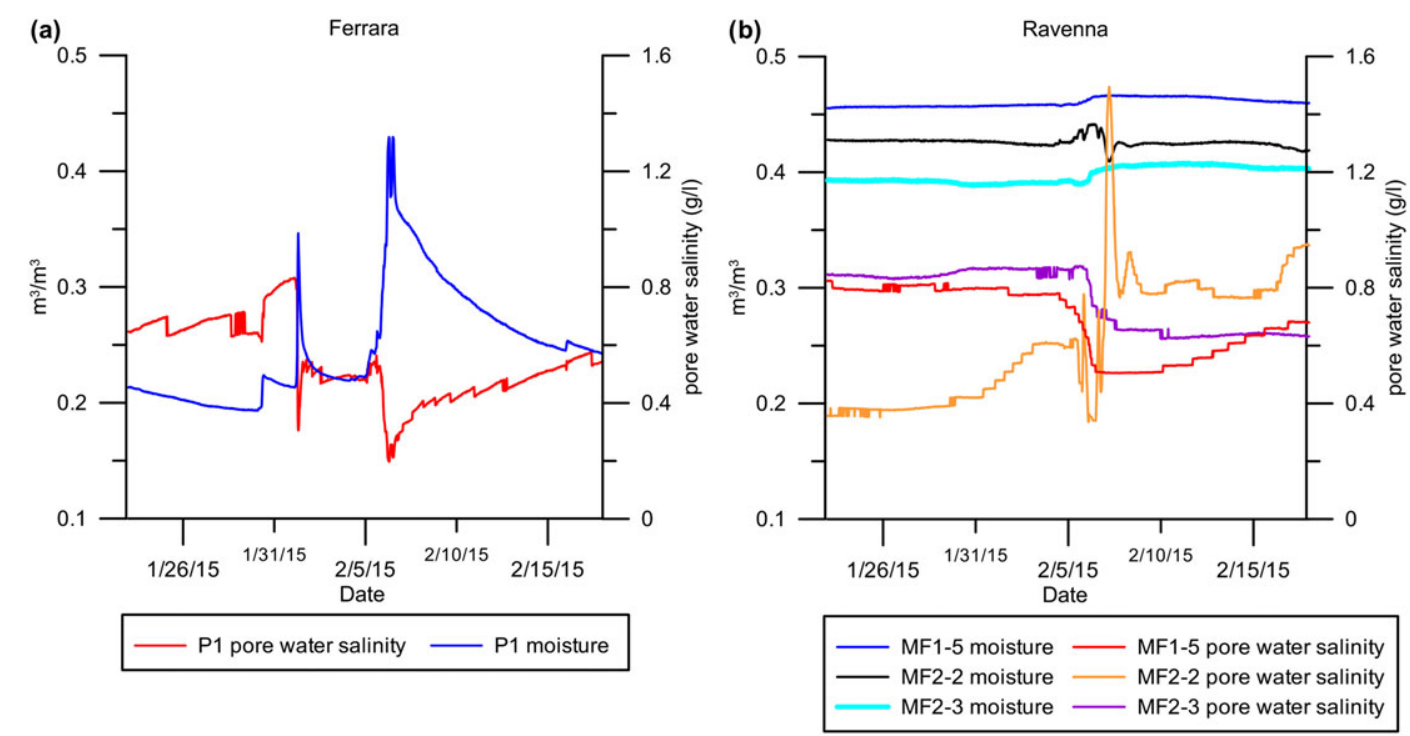

FIGURE 4 Soil moisture $\left(\mathrm{m}^{3} / \mathrm{m}^{3}\right)$ and pore water salinity $(\mathrm{g} / \mathrm{L})$ recorded at the depth of about $0.4-0.5 \mathrm{~m}$ below the ground in both study areas (refer to Figure 1 for the location of the monitoring points). Soil moisture curves refer to the left axes, and pore water salinity curves refer to the right axes 

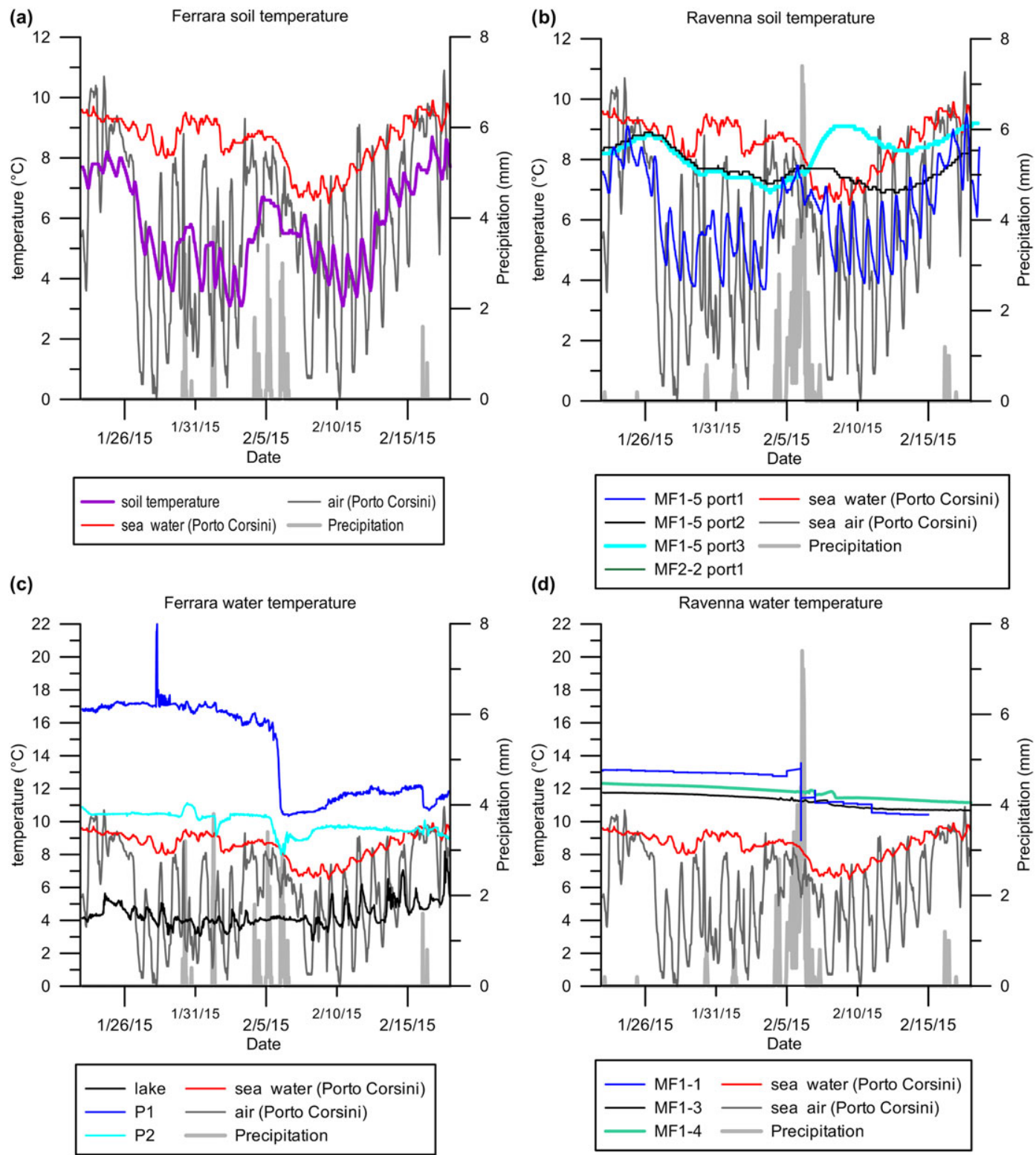

FIGURE 5 Soil and water temperature values $\left({ }^{\circ} \mathrm{C}\right.$ ) recorded by level-loggers and soil probes in both study areas (refer to Figure 1 for the location of the monitoring points). Sea water and air temperature data from the tide gauge at Porto Corsini (Ravenna) are also shown

Regarding groundwater temperature, the storm event caused a general and rapid decrease of $1-2^{\circ} \mathrm{C}$, with a maximum decrease of $5{ }^{\circ} \mathrm{C}$ recorded in $\mathrm{P} 1$ at the Ferrara site and $4{ }^{\circ} \mathrm{C}$ in MF1-1 at the Ravenna site.

\section{4 | DISCUSSION}

The storm event on February 5-6, 2015 caused a general increase in the hydraulic head of the shallow coastal aquifer (Figure 2). The closer to the coastline, the stronger was the impact on the $H_{f}$ (MF 1-1; Figure 2b), but the effect was already limited about $300 \mathrm{~m}$ from the coastline (P2 in Figure 2a and MF2-3 in Figure 2b).

The storm caused a general and temporary decrease in groundwater salinity along the coastal aquifer, except for the piezometer MF1-1, which is the closest to the coast (only $80 \mathrm{~m}$ from the coastline). The extreme salinity decrease in P1 at the Ferrara site (Figure 3a) was most probably due to a losing storm water and household collector system, located at approximately $5 \mathrm{~m}$ from $\mathrm{P} 1$, which led to preferential infiltration of rainwater in the fully screened monitoring well, inducing artificial mixing within the monitoring well (Colombani, Volta, Osti, \& Mastrocicco, 2016c). This is also witnessed by the sharp salinity decrease of approximately $10 \mathrm{~g} / \mathrm{L}$ that occurred on January 28 , 2015 , without any precipitation recorded by the nearby meteorological station. On the other hand, the salinity peak shown in Figure 3b is caused by the storm waves that persisted right on the dune crest and that caused infiltration of saline water through the vadose zone down to the saturated portion of the aquifer. This upper saline plume formed by storm waves on the dune crest is evident in Figure $3 \mathrm{~b}$ (MF1-1) and Figure 4 (MF2-2b) and was also observed in previous studies (Holding \& Allen, 2015; Illangasekare et al., 2006). This increase in pore water salinity through the vadose zone and the temporary disappearance of the freshwater lens that is generally present confirm the dominant role of the dune system, not only as a physical barrier to 
inundation but also as a freshwater reservoir in coastal areas. A wellpreserved dune system (topographically elevated, with stable profile and vegetation) would better resist to extreme events, avoiding the deterioration of freshwater resources in coastal areas. This would be true not only for Mediterranean climatic conditions but also for tropical climatic conditions often affected by cyclones (Smith, Cable, \& Martin, 2008) and especially in view of the projected climate changes (Cayan et al., 2008). As suggested in Holding and Allen (2015), the hydraulic properties of the vadose and saturated zones (Figures 4 and 5) control the flow of water and mass transport of salt within the aquifer. The hydraulic properties of the vadose zone determine the extent and advective velocity of saltwater contamination occurring during the inundation and the formation of the saline plume caused by storm waves impacting directly on top of the dunes. If the vadose zone has relatively high hydraulic conductivity, as in these sandy coastal dunes, the mass transport of salt into the aquifer is facilitated during the inundation, resulting in a large saltwater plume. Soil and water parameters in the vadose zone (Figure 2) recovered quickly after the storm ended. As highlighted by Illangasekare et al. (2006), high hydraulic conductivities, as those measured in the investigated coastal aquifer, can help freshwater lenses to recover quickly due to increased advective movement of the saltwater plume down to the aquifer. Thus, after the washover event ceased, the saline plume migrated downward and dispersed over time. On the other hand, despite the high hydraulic conductivity, the aquifer system did not quickly recover: in fact, the storm effects were still evident in both groundwater ( $H_{f}$ and salinity) and soil parameters in the vadose zone (temperature, soil moisture, and pore water salinity) even after 10 days since the storm-wave washover had ceased.

Chui and Terry (2012) showed how highly permeable sands retain minimal moisture in the unsaturated zone, leaving ample pore space to allow rapid seawater ingression during washover by storm waves. This could explain the rapid increase in groundwater salinity in MF1-1 (Figure 3b). The storm event was able to fill up the unsaturated zone (flooded areas were observed also a couple of days after the storm) and cause salinization of the freshwater lenses present before the storm. Nonetheless, the seawater storm waves affected directly just a relatively small area, because only one monitoring piezometer placed near the coast recorded such variations. All other monitoring piezometers recorded a decrease in salinity due to the heavy recharge from rainfalls that occurred during the storm event. Moreover, the long screen monitoring well P1 in the Ferrara site showed misleading results with respect to the shallow piezometers that accurately represented the actual $H_{f}$ and salinity present at the top of the aquifer. The Nazioni Lake recorded no change in salinity during the storm event, and this was due to its large inertia induced by faster lake water mixing rate compared to groundwater.

Regarding temperature dataset, soil and sea surface show a similar temperature trend, although more attenuate than air temperature oscillations (Figure 5a,b), with the only exception of piezometer MF1-5 filter port 3, which recorded a sudden pulse increase in temperature after the storm event, most probably due to the groundwater upwelling induced by the storm (Figure 2). Groundwater, in fact, was at higher temperature with respect to the infiltrating rainwater (Figure 5).
The storm event caused a rapid decrease in groundwater temperature (Figure $5 c, d)$, and the maximum decrease in P1 at the Ferrara site can be explained by the rapid water infiltration from the storm water and household collector system, witnessed by the extreme rise of the groundwater temperature up to $22{ }^{\circ} \mathrm{C}$ on January 28,2015 , when some household warm water was leaked in the system.

The temperature recorded in the Nazioni Lake was influenced by air temperature because of the shallow position of the level-logger, about $-0.20 \mathrm{~m}$ below the water surface, gently smoothing the daily temperature variations that occurred throughout the monitoring period. Overall, the employed monitoring techniques are limited in space and should be corroborated by nonpoint data such as geophysical measurements to extend the observed high-quality data in between the monitored points. Thus, future works will need to tackle better this point using for instance time-lapse geophysical measurements to extend laterally the observed results.

\section{5 | CONCLUSIONS}

This research brings new data and insight on the effects of extreme storm events on unconfined coastal aquifers. The data were evaluated comparing two different sites pertaining to the same coastal aquifer of the Emilia-Romagna region, Italy.

The storm effects were evaluated by monitoring both the saturated and vadose zone parameters such as equivalent freshwater heads, temperature and salinity of groundwater and soil temperature, and salinity and volumetric water content. This database allowed inferring the magnitude and extent of the extreme storm event on the coastal aquifer. The main outcomes are a general increase in hydraulic head and soil moisture, along with a decrease in groundwater salinity and pore water salinity due to the rainfall infiltration during the 2 days storm event. The noticeable exceptions are represented by the observation points in proximity to the coastline (within $100 \mathrm{~m}$ ), which recorded a temporary increase in soil and water salinity caused by the exceptional high waves, which persist right on top of the dune crest during the storm event. This generates an upper saline plume that infiltrates through the vadose zone down to the saturated portion of the aquifer causing a temporary disappearance of the freshwater lens generally present below the coastal dunes. Despite the high hydraulic conductivity, the aquifer system does not quickly recover itself and the storm effects are still evident in groundwater and soil parameters after 10 days past the end of the storm-wave washover. The above-mentioned effects due to storm events are likely to occur in other similar sedimentary coastal settings throughout the world.

\section{ACKNOWLEDGMENTS}

We gratefully thank the Geological, Seismic and Soil Survey of Emilia-Romagna Region for its technical and scientific support, and the State Forestry Corps for providing the access to the natural protected area of Lido di Dante pine forest. Part of this research was supported by Fondazione Flaminia within the cooperation project "RIDEG-RA-Restoration and management of coastal dunes in Ravenna coast." 


\section{REFERENCES}

Amorosi, A., Colalongo, M. L., Pasini, G., \& Preti, D. (1999). Sedimentary response to Late Quaternary sea-level changes in the Romagna coastal plain (northern Italy). Sedimentology, 46, 99 121. doi:10.1046/j.13653091.1999.00205.x

Amorosi, A., Maselli, V., \& Trincardi, F. (2016). Onshore to offshore anatomy of a Late Quaternary source-to-sink system (Po Plain Adriatic Sea, Italy). Earth-Science Reviews, 153, 212 237. doi:10.1016/j. earscirev.2015.10.010

Anderson, J. W. P. (2002). Aquifer salinization from storm overwash. Journal of Coastal Research, 18(3), 413420.

Antonellini, M., Mollema, P., Giambastiani, B. M. S., Bishop, K., Caruso, L., Minchio, A., ... Gabbianelli, G. (2008). Saltwater intrusion in the coastal aquifer of the southern Po Plain, Italy. Hydrogeology Journal, 16(8), 1541 1556. doi:10.1007/s10040-008-0319-9

Armaroli, C., Ciavola, P., Perini, L., Calabrese, L., Lorito, S., Valentini, A., \& Masina, M. (2012). Critical storm thresholds for significant morphological changes and damages along the Emilia-Romagna coastline, Italy. Geomorphology, 143(34), 551 556. doi:10.1016/j. geomorph.2011.09.006

ARPAe, 2010. Annuario dei dati ambientali. Acque di transizione, capitolo 3D. ARPA Emilia-Romagna 356423.

ARPAe, 2015. Rapporto dell'evento meteorologico del 5 e 6 febbraio 2015. ARPA Emilia-Romagna, Servizio Idro-Meteo-Clima, Bologna 12/02/ 2015: 36 pp.

Balugani, E., \& Antonellini, M. (2011). Barometric pressure influence on water table fluctuations in coastal aquifers of partially enclosed seas: An example from the Adriatic coast, Italy. Journal of Hydrology, 400, 176 186. doi:10.1016/j.jhydrol.2011.01.040

Cartwright, N., Li, L., \& Nielsen, P. (2004a). Response of the salt freshwater interface in a coastal aquifer to a wave-induced groundwater pulse: Field observations and modelling. Advances in Water Resources, 27, 297 303. doi:10.1016/j.advwatres.2003.12.005

Cartwright, N., Nielsen, P., \& Li, L. (2004b). Experimental observations of watertable waves in an unconfined aquifer with a sloping boundary. Advances in Water Resources, 27, 991 1004. doi:10.1016/j. advwatres.2004.08.006

Caschetto, M., Colombani, N., Mastrocicco, M., Petitta, M., \& Aravena, R. (2016). Estimating groundwater residence time and recharge patterns in a saline coastal aquifer. Hydrological Processes.. doi:10.1002/ hyp.10942

Castaldelli, G., Soana, E., Racchetti, E., Pierobon, E., Mastrocicco, M., Tesini, E., ... Bartoli, M. (2013). Nitrogen budget in a lowland coastal area within the Po river basin (northern Italy): Multiple evidences of equilibrium between sources and internal sinks. Environmental Management, 52(3), 567 580. doi:10.1007/s00267-013-0052-6

Cayan, D. R., Bromirski, P. D., Hayhoe, K., Tyree, M., Dettinger, M. D., \& Flick, R. E. (2008). Climate change projections of sea level extremes along the California coast. Climatic Change, 87(1), 5773. doi:10.1007/s10584-007-9376-7

Chui, T. F. M., \& Terry, J. P. (2012). Modeling fresh water lens damage and recovery on atolls after storm-wave washover. Ground Water, 50(3), 412420.

Ciavola, P., Armaroli, C., Chiggiato, J., Valentini, A., Deserti, M., Perini, L., \& Luciani, P. (2007). Impact of storms along the coastline of EmiliaRomagna: The morphological signature on the Ravenna coastline (Italy). Journal of Coastal Research, 5, 15.

Colombani, N., Osti, A., Volta, G., \& Mastrocicco, M. (2016a). Impact of climate change on salinization of coastal water resources. Water Resources Management, 30(7), 2483 2496. doi:10.1007/s11269-016-1292-z

Colombani, N., Di Giuseppe, D., Faccini, B., Ferretti, G., Mastrocicco, M., \& Coltorti, M. (2016b). Inferring the interconnections between surface water bodies, tile-drains and an unconfined aquifer aquitard system: A case study. Journal of Hydrology, 537, 86 95. doi:10.1016/j. jhydrol.2016.03.046
Colombani, N., Volta, G., Osti, A., \& Mastrocicco, M. (2016c). Misleading reconstruction of seawater intrusion via integral depth sampling. Journal of Hydrology, 536, 320 326. doi:10.1016/j.jhydrol.2016.03.011

Corbau, C., Simeoni, U., Melchiorre, M., Rodella, I., \& Utizi, K. (2015). Regional variability of coastal dunes observed along the EmiliaRomagna littoral, Italy. Aeolian Research, 18, 169 183. doi:10.1016/j. aeolia.2015.07.001

Decagon Devises, 2015. 5TE, water content, EC and temperature sensor Manual of Decagon Devices, Inc.: 26 pp.

Giambastiani, B. M. S., Antonellini, M., Oude Essink, G. H. P., \& Stuurman, R. J. (2007). Saltwater intrusion in the unconfined coastal aquifer of Ravenna (Italy): A numerical model. Journal of Hydrology, 340, 91104. doi:10.1016/j.jhydrol.2007.04.001

Giambastiani, B. M. S., Colombani, N., Mastrocicco, M., \& Fidelibus, M. D. (2013). Characterization of the lowland coastal aquifer of Comacchio (Ferrara, Italy): Hydrology, hydrochemistry and evolution of the system. Journal of Hydrology, 501, 3544. doi:10.1016/j. jhydrol.2013.07.037

Giambastiani, B. M. S., Greggio, N., Pacella, K., lodice, A., Antonellini, M.. 2014. Effect of forest fire on coastal aquifer salinisation and freshwater availability. In Proceedings: 23nd SWIM Salt Water Intrusion Meeting, pp. 125 128. Husum, Germany, 1620 June 2014.

Giuliano, A., \& Manda, A. K. (2012). Wind driven salinity distributions in the Emily and Richardson Preyer Buckridge Coastal Reserve, Southern Alligator River Estuarine System, Eastern North Carolina. Geological Society of America (GSA) Abstracts with Programs, 44, 59.

Guo, H., Jiao, J., \& Li, H. (2010). Groundwater response to tidal fluctuation in a two-zone aquifer. Journal of Hydrology, 381, 364371. doi:10.1016/j.jhydrol.2009.12.009

Harley, M. D., Valentini, A., Armaroli, C., Perini, L., Calabrese, L., \& Ciavola, P. (2015). Can an early warning system help minimize the impacts of coastal storms? A case study of the 2012 Halloween storm, northern Italy. Natural Hazards and Earth System Sciences, 3, 3409 3448. doi:10.5194/nhess-16-209-2016

Hilhorst, M. A. (2000). A pore water conductivity sensor. Soil Science Society of America Journal, 64(6), 1922 1925. doi:10.2136/sssaj2000. $6461922 x$

Holding, S., \& Allen, D. M. (2015). Wave overwash impact on small islands: Generalized observations of freshwater lens response and recovery for multiple hydrogeological settings. Journal of Hydrology, 529, 1324 1335. doi:10.1016/j.jhydrol.2015.08.052

Illangasekare, T., Tyler, S. W., Clement, T. P., Villholth, K. G., Perera, A. P. G. R. L., Obeysekera, J., ... Jensen, K. (2006). Impacts of the 2004 tsunami on groundwater resources in Sri Lanka. Water Resources Research, 42(5), W05201. doi:10.1029/2006WR004876

IPCC (2001). Climate change 2001: Impacts, adaptation, and vulnerability. In J. J. McCarthy, O. F. Canziani, N. A. Leary, D. J. Dokken, \& K. S. White (Eds.), Contribution of Working Group II to the Third Assessment Report of the Intergovernmental Panel on Climate Change). Cambridge, United Kingdom and New York, NY, USA: Cambridge University Press.

IPCC (2012). Managing the risks of extreme events and disasters to advance climate change adaptation. In C. B. Field, V. Barros, T. F. Stocker, D. Qin, D. J. Dokken, K. L. Ebi, et al. (Eds.), A special report of Working Groups I and II of the Intergovernmental Panel on Climate Change (pp. 582). Cambridge, UK, and New York, NY, USA: Cambridge University Press.

IPCC (2013). Climate change 2013: The physical science basis. In T. F. Stocker, D. Qin, G.-K. Plattner, M. Tignor, S. K. Allen, J. Boschung, et al. (Eds.), Contribution of Working Group I to the Fifth Assessment Report of the Intergovernmental Panel on Climate Change (pp. 1535). Cambridge, United Kingdom and New York, NY, USA: Cambridge University Press.

Ketabchi, H., Mahmoodzadeh, D., Ataie-Ashtiani, B., \& Simmons, C. T. (2016). Sea-level rise impacts on seawater intrusion in coastal aquifers: 
Review and integration. Journal of Hydrology, 535, 235255. doi:10.1016/j.jhydrol.2016.01.083

Lewis, E. L., \& Perkin, R. G. (1981). The practical salinity scale 1978: Conversion of existing data. Deep Sea Research Part A Oceanographic Research Papers, 28(4), 307328.

Masina, M., Lamberti, A., \& Archetti, R. (2015). Coastal flooding: A copula based approach for estimating the joint probability of water levels and waves. Coastal Engineering, 97, 37 52. doi:10.1016/j. coastaleng.2014.12.010

Mastrocicco, M., Giambastiani, B. M. S., Severi, P., \& Colombani, N. (2012). The importance of data acquisition techniques in saltwater intrusion monitoring. Water Resources Management, 26, 28512866. doi:10.1007/s11269-012-0052-y

Mistri, M., \& Rossi, R. (1999). Structure and production of the benthic macroinvertebrate community in a shallow lagoon of the Po River Delta. Italian Journal of Zoology, 66(4), 361 368. doi:10.1080/11250 009909356278

Nielsen, P. (1999). Groundwater dynamics and salinity in coastal barriers. Journal of Coastal Research, 15(3), 732 740. DOI:

Perini, L., Calabrese, L., Lorito, S., \& Luciani, P. (2015). II rischio da mareggiata in Emilia-Romagna: l'evento del 5-6 febbraio 2015. II Geologo, 117.

Perini, L., Calabrese, L., Salerno, G., Ciavola, P., \& Armaroli, C. (2016). Evaluation of coastal vulnerability to flooding: Comparison of two different methodologies adopted by the Emilia-Romagna region (Italy). Natural Hazards and Earth System Sciences, 16(1), 181 194. doi:10.5194/ nhess-16-181-2016

Post, V. E. A., Kooi, H., \& Simmons, C. T. (2007). Using hydraulic head measurements in variable-density ground water flow analyses. Ground Water, 45(6), 664 671. doi:10.1111/j.1745-6584.2007.00339.x

Robinson, C., Xin, P., Li, L., \& Barry, D. A. (2014). Groundwater flow and salt transport in a subterranean estuary driven by intensified wave conditions. Water Resources Research, 50, 165 181. doi:10.1002/ 2013WR013813

Smith, C. G., Cable, J. E., \& Martin, J. B. (2008). Episodic high intensity mixing events in a subterranean estuary: Effects of tropical cyclones.
Limnology and Oceanography, 53(2), 666 674. doi:10.4319/ lo.2008.53.2.0666

Sytnik, O., \& Stecchi, F. (2014). Disappearing coastal dunes: Tourism development and future challenges, a case-study from Ravenna, Italy. Journal of Coastal Conservation, 19(5), 715 727. doi:10.1007/s11852-014-0353-9

Taramelli, A., Di Matteo, L., Ciavola, P., Guadagnano, F., \& Tolomei, C. (2015). Temporal evolution of patterns and processes related to subsidence of the coastal area surrounding the Bevano River mouth (Norther Adriatic) Italy. Ocean and Coastal Management, 108, 7488. doi:10.1016/j.ocecoaman.2014.06.021

Terry, J. P., \& Falkland, A. C. (2010). Responses of atoll freshwater lenses to storm-surge overwash in the Northern Cook Islands. Hydrogeology Journal, 18, 749 759. doi:10.1007/s10040-009-0544-x

Vallejos, A., Sola, F., \& Pulido-Bosch, A. (2015). Processes influencing groundwater level and the freshwater saltwater interface in a coastal aquifer. Water Resources Management, 29(3), 679 697. doi:10.1007/ s11269-014-0621-3

Werner, A. D., \& Simmons, C. T. (2009). Impact of sea-level rise on sea water intrusion in coastal aquifers. Ground Water, 47(2), 197204. doi:10.1111/j.1745-6584.2008.00535.x

Xin, P., Robinson, C., Li, L., Barry, D. A., \& Bakhtyar, R. (2010). Effects of wave forcing on a subterranean estuary. Water Resources Research, 46, W12505. doi:10.1029/2010WR009632

Yang, J., Graf, T., Herold, M., \& Ptak, T. (2013). Modelling the effects of tides and storm surges on coastal aquifers using a coupled surface subsurface approach. Journal of Contaminant Hydrology, 149, 6175. doi:10.1016/j.jconhyd.2013.03.002

How to cite this article: Giambastiani BMS, Colombani N, Greggio N, Antonellini M, Mastrocicco M. Coastal aquifer response to extreme storm events in Emilia-Romagna, Italy. Hydrological Processes. 2017;31:1613-1621. https://doi.org/ 10.1002/hyp.11130 